\title{
Furuncular Botfly Myiasis - A Case Report
}

\author{
Juliana GAO1, Vera TEŠIĆ², Vesna PETRONIĆ ROSIĆ1 \\ ${ }^{1}$ Section of Dermatology, Department of Medicine, The University of Chicago, Chicago, IL, USA \\ ${ }^{2}$ Department of Pathology, The University of Chicago, Chicago, IL, USA \\ *Correspondence: Vesna Petronić Rosić, E-mail: vprosic@uchicago.edu \\ UDC 616.5:616.993
}

\begin{abstract}
Botfly myiasis is an infestation of the skin or a body cavity by developing larvae of Dermatobia hominis, one of the most common flies that cause human infestation among the local population, in regions ranging from Mexico into South America and in travelers. The life cycle starts when a female fly glues the eggs to the vector, a blood-sucking arthropod, which carries the unhatched larvae to the susceptible host. A case of furuncular botfly myiasis in an 85 year-old female with recent travel to Belize is presented here to highlight the parasite life cycle and review the different treatment options.
\end{abstract}

Key words: Skin Diseases, Parasitic; Myiasis; Travel; Diptera; Scalp Dermatoses; Insects; Belize; Larva

\section{Case Report}

An 85 year-old Caucasian female presented to dermatology clinic for evaluation of a growing nodule on the scalp that was accompanied by intermittent stabbing and shooting pain. Prior to the onset of symptoms, the patient had traveled to India and Belize, returning to the United States just a few weeks prior to presentation. Initial examination in clinic showed a $1 \mathrm{~cm}$ subcutaneous nodule with overlying linear erosion and hemorrhagic crust (Figure 1A). The lesion was thought to be a cyst and thus she was scheduled for excision.

Examination in procedure clinic showed a $2.5 \mathrm{~cm}$ subcutaneous nodule with a central $1 \mathrm{~mm}$ "punched-out" opening. After the area was prepped and anesthetized, a standard fusiform incision was made over the subcutaneous nodule. Upon removal of the overlying skin, a $1.2 \mathrm{~cm}$ yellow striated larva was identified (Figure 1B). The larva was alive and moving at the time. The specimen was then sent to microbiology, and the larva was identified as Dermatobia hominis by the characteristic rows of posteriorly directed spines (Figure 2).

The patient was empirically started on cephalexin $500 \mathrm{mg}$ twice a day for a total of ten days. A head CT was obtained and did not show evidence of skull or sinus involvement. At one week follow up, she was healing well and reported resolution of the stabbing and shooting pain over the area.

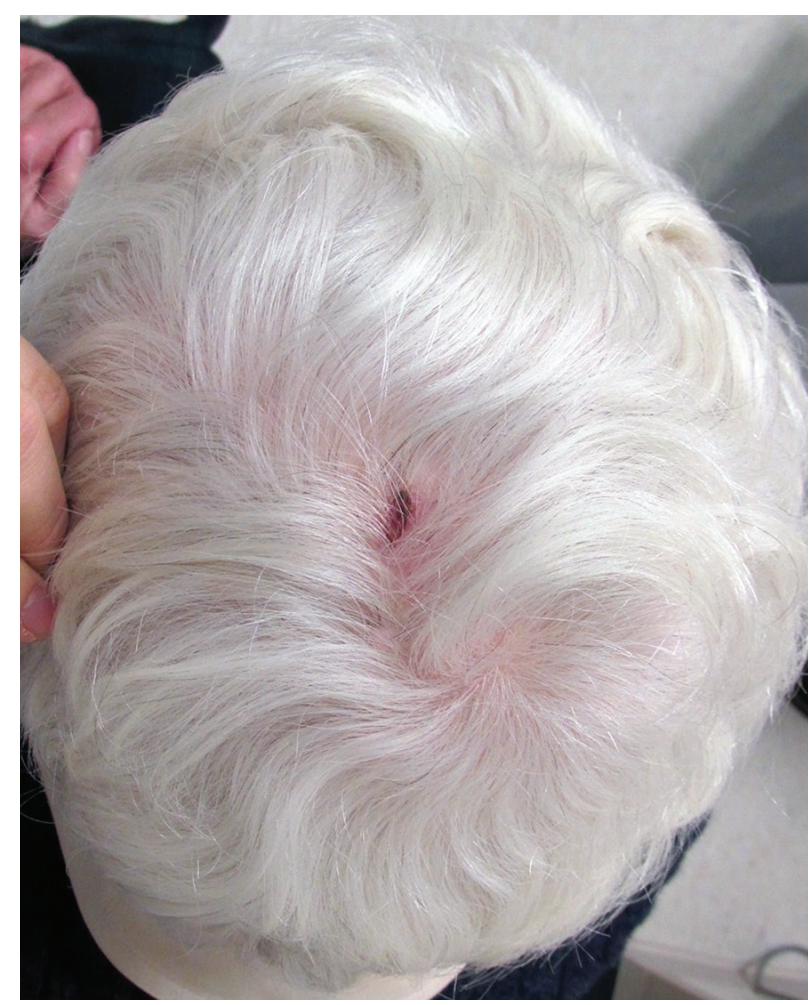

Figure 1A. $1 \mathrm{~cm}$ subcutaneous nodule with overlying linear erosion and hemorrhagic crust 


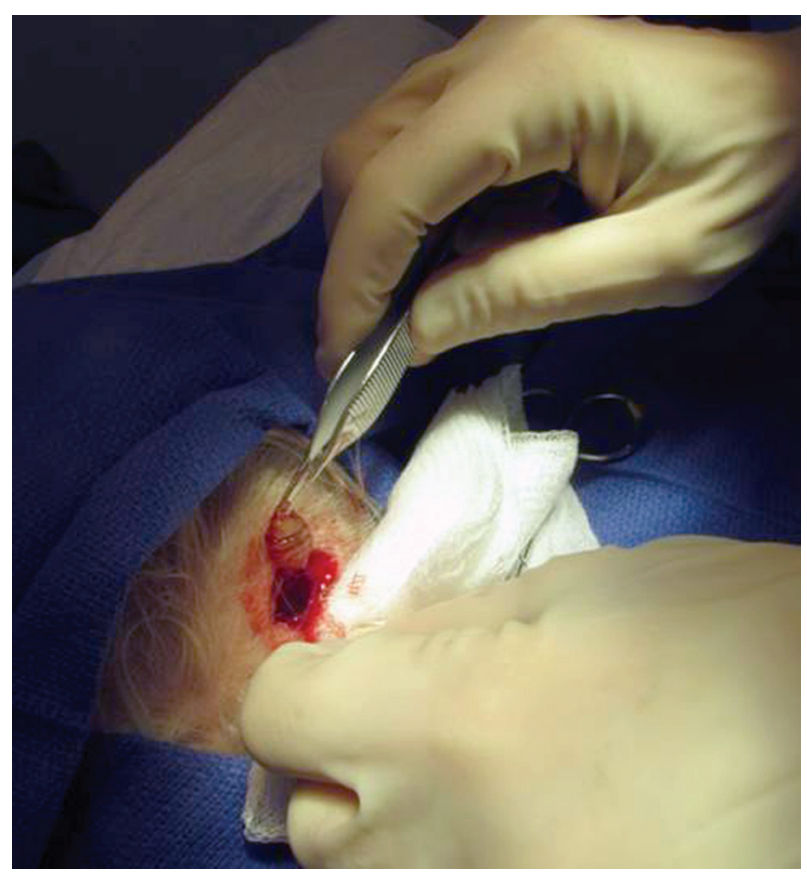

Figure 1B. Removal of a $1.2 \mathrm{~cm}$ yellow striated larva from fusiform opening

\section{Discussion}

Geographic locations of cutaneous myiasis are usually limited to the tropical and subtropical areas, including countries in Central America, South America, and Africa. It is very uncommon within the United States, and the majority of patients had recent travel to topical areas (1). Dermatobia hominis (human

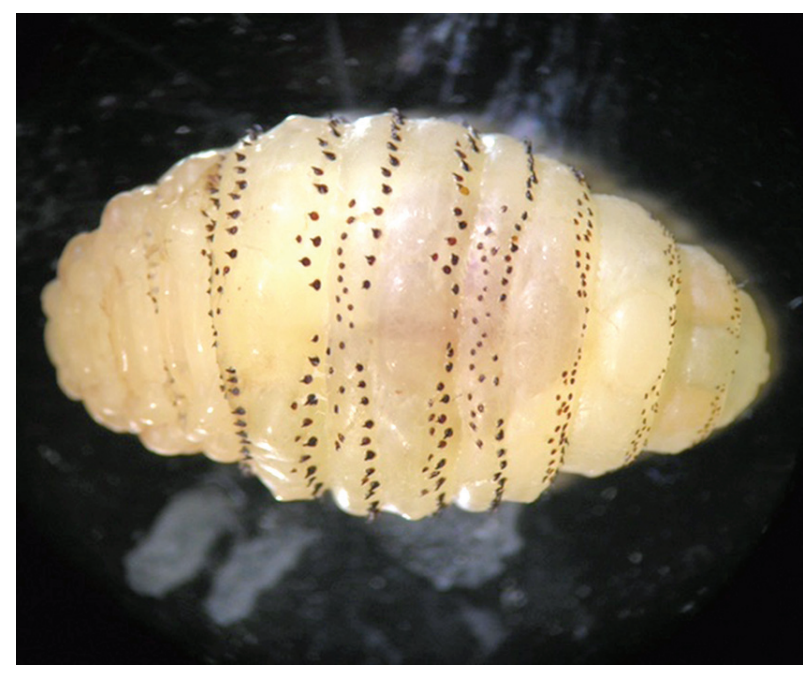

Figure 2. Dermatobia hominis with characteristic rows of posteriorly directed spines botfly) and Cordylobia anthropophaga (African tumbu fly) are the two most common causes of furuncular myiasis worldwide. Patients with open wounds can also develop wound botfly myiasis. Cavitary myaisis is possible in cases when larva is deposited near facial orifices, where it can then burrow deeper to involve the nearby sinuses (2).

The life cycle of a botfly involves a bloodsucking arthropod as well as a warm-blooded host (mammal or avian). The adults of D.hominis are free living. During breeding, they lay eggs on the bodies of mosquitos, where they are cemented via a glue-like substance. Larvae develop within the eggs and remain there until the arthropod comes in contact with a warm-blooded host during feeding. Once in contact with the host, the larva penetrates into the skin and remains in a subdermal cavity for the next 5 to 10 weeks where it feeds on the host as it matures. Typically, these present as boil-like lesions with a central punctum which functions as a breathing hole for the larva. Once the larva matures, it burrows through the breathing hole and drops to the ground where it pupates and becomes a free living botfly (3).

During their course of maturation, botfly myaisis usually does not pose any danger to the host. Patients may experience pruritus, sensations of movement and lancinating pain, which may be explained by rotational movement of the larvae and its rows of hooklets (4). Secondary bacterial infections with Staphylococcus and Group B streptococcus have been reported $(5,6)$. Overall, furuncular myiasis is a self-limited infestation as the larvae will eventually leave the host; however, leaving the parasite to perform its natural cycle is generally not recommended (2).

There are several methods used for the extractions of the botfly larvae. Traditional folk remedy calls for a strip of bacon over the central punctum to suffocate the larvae, which forces it to surface for air over the course of several hours, at which point the larva can then be gently extracted with a forceps. This can also be accomplished using petroleum jelly, liquid paraffin, beeswax, or even nail polish (7). Other authors have advocated the use of $1 \%$ lidocaine to paralyze the parasite, and liquid nitrogen to stiffen the larvae for easier extraction $(8,9)$. In most cases, surgi- 
cal excisions and extractions are unnecessary, but can be done under local anesthesia if other methods of extractions are unsuccessful (10). Antibiotics are recommended if there are signs or symptoms of secondary bacterial infection (2).

\section{Conclusion}

Botfly myiasis represents an interesting parasitic infection transmitted by blood-sucking arthropod. Its unique life cycle leads to delayed symptom onset and diagnosis. It is a common condition in tropical and subtropical continent though rarely seen in the more temperate climate except for travelers. We present this case of furuncular myiasis for clinical interest.

\section{References}

1. Center for Disease Control and Prevention. Myiasis FAQs (Internet). (updated 2014 Apr 1; cited 2018 Apr 15). Available from: https://www.cdc.gov/parasites/ myiasis/faqs.html.
2. Francesconi F, Lupi O. Myiasis. Clin Microbiol Rev. 2012;5(1):79-105.

3. Center for Disease Control and Prevention. Myiasis: biology (Internet). (updated 2013 Jul 19; cited 2018 Apr 15). Available from: https://www.cdc.gov/parasites/myiasis/biology.html.

4. Hunter JM. Bot-fly maggot infestation in Latin America. Geogr Rev. 1990;80(4):382-9.

5. Gordon PM, Hepburn NC, Williams AE, Bunney MH. Cutaneous myiasis due to Dermatobia hominis: a report of six cases. Br J Dermatol. 1995;132(5):811-4.

6. Hubler WR Jr, Rudolph AH, Dougherty EF. Dermal myiasis. Arch Dermatol. 1974;110(1):109-10.

7. Brewer TF, Wilson ME, Gonzalez E, Felsenstein D. Bacon therapy and furuncular myiasis. JAMA. 1993;270(17):2087-8.

8. Loong PT, Lui H, Buch HW. Cutaneous myaisis: a simple and effective technique for extraction of Dermatobia hominis larvae. Int J Dermatol. 1992;31(9):657-9.

9. Sharma P, Pai HS, Pai GS. Furuncular myaisis mimicking pyoderma. Indian J Deramatol Venereol Leprol. 2008;74(6):679-81.

10. Brent AJ, Hay D, Conlon CP. Souvenirs to make your skin crawl. Lancet Infect Dis. 2008;8(8):524.

\section{Furunkularna botfly mijaza - prikaz slučaja}

\section{Sažetak}

Botfly mijaza je infestacija kože ili telesne šupljine larvama Dermatobia homini, jedne od najčešćih muva koje izazivaju infestaciju kod lokalnog stanovnišva, u regionima od Meksika do Južne Amerike i kod putnika. Životni ciklus počinje kada ženka položi jaja na vektor, insekt krvopiju, koji prenosi neizležene larve na podložnog domaćina. Ovde je prikazan slučaj furunkularne botfly mijaze kod žene stare 85 godina koja je nedavno putovala u Belize da bi se objasnio životni ciklus parazita i dao uvid u različite opcije lečenja.

Ključne reči: Parazitske kožne bolesti; Myiasis; Putovanja; Dvokrilci; Dermatoze kože glave; Insekti; Belize; Larve 